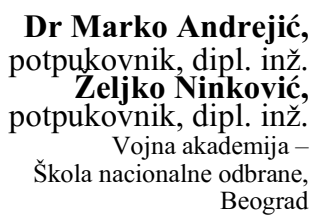

\section{ORGANIZACIJA RADA U JEDINICAMA TEHNIČKE SLUŽBE U BORBENIM \\ DEJSTVIMA}

UDC: $358.3: 65.01$

Rezime:

U radu se obrađuje organizacija rada u jedinicama tehničke službe u združenim taktičkim jedinicama, osloncem na sistematizovana iskustva, postojeću normativu i dostupna teorijska saznanja. Jedinice tehničke službe posmatraju se kao složeni organizacioni sistem, sa različitih aspekata. Analitičko-sintetičkim pristupom razmatraju se raspored jedinica tehničke službe, principi organizacije rada, organizacije radnog mesta i individualnog rada, prostorna integracija elemenata stanica i sekcija, izbor rejona razmeštaja jedinica tehničke službe, razvijanje $i$ uređenje stanica i organizacija rada u stanicama za snabdevanje $i$ održavanje.

Ključne reči: organizacija rada, jedinice tehničke službe, principi organizacije rada, prostorna integracija, razvoj i uređenje stanica.

\title{
ORGANIZATION OF TECHNICAL SERVICE SUPPORT UNITS IN COMBAT OPERATIONS
}

Summary:

In this paper it has been presened organization of technical service support in joined tactical military unit, based on systemized recent experiences, existing normative rules and available teoretical knowledge. Technical service support units are considered as complex organization system from different standpoint. Using analitycal - syntetical methodology it has been examened technical service support units deployment, work organization principles, individual work place organization, spatial integration of service stations and sections, choice of units deployment regions and, work organization in station for supply and maintenance.

Key words: work organization technical units, principles of work organization, spatial integation, development and maintenance of stations.

\section{Uvod}

U operativnoj praksi vrlo često se govori o potrebi organizovanog rada $u$ jedinicama tehničke službe (TSl) u borbenim dejstvima, iako se retko (u normativi i pisanim radovima) eksplicitno objašnjava šta se pod time podrazumeva. Takođe, u malom broju naslova nastavno-obrazovne literature obrađuje se ova oblast. Slično stanje je i pri organizovanju rada $u$ ostalim logističkim jedinicama.
Pri razmatranju organizovanja rada u jedinicama TS1 u ZTJ neophodno ih je razmatrati kao složeni organizacioni sistem, i to kao: proizvodno-uslužni sistem, sistem podrške, poslovni sistem i borbeni sistem. Ovakav način posmatranja logističkih jedinica relativno je nov, a nametnule su ga potrebe prakse, zahtevi vremena i savremeni upravljački i logistički trendovi.

Postojeća normativna regulativa uglavnom je jedinice TSl, kao složene 
organizacione sisteme, posmatrala bez sagledavanja složenosti i celovitosti njihovog funkcionisanja i upotrebe.

Potrebe prakse, zahtevi vremena i savremeni trendovi u izučavanju logističkih jedinica zahtevaju njihovo celovito sagledavanje i posmatranje funkcionisanja i upotrebe sa različitih aspekata.

Postojeća normativna regulativa predstavlja solidnu osnovu za upotrebu jedinica TS1 u ZTJ u borbenim dejstvima, ali je potrebno da se bolje sistematizuje, aktuelizuje, operacionalizuje i unapredi, a da se postojeća rešenja organizaciono modernizuju.

Adekvatna upotreba jedinica TS1 u borbenim dejstvima nije jednostavna, jer u uslovima često vrlo nepovoljnog delovanja okruženja treba, na nedovoljno poznatoj lokaciji, od ograničenih resursa, u ograničenom vremenu i na ograničenom prostoru, uspostaviti sistem koji ostvaruje kvalitetnu prostornu integraciju svojih elemenata i podsistema, izvršava namenske zadatke i funkcioniše po određenim principima - efikasno i efektivno.

Funkcionisanje i upotreba logističkih jedinica na taktičkom nivou organizovanja Vojske nedovoljno se obrađuje $u$ našim vojnim časopisima, pa je cilj ovog rada da se ukaže na problem i potrebu za njegovim rešavanjem, da se pruži konkretan doprinos unapređenju trupne prakse i posluži kao polazna osnova za dalja teorijska razmatranja i za dogradnju funkcionisanja i upotrebe jedinica TSl u borbenim dejstvima, osloncem na sistematizovana iskustva i dostupna teorijska saznanja. Mogućnost učešća logističkih jedinica, ili njihovih delova, u raznim mirovnim misijama, takođe, doprinosi aktuelnosti ove problematike.
Da bi rad jedinica TSl u borbenim dejstvima bio efikasan i efektivan neophodno je da se primenjuju određeni principi: organizacije rada, organizacije radnog mesta i individualnog rada.

Principi organizacije rada predstavljaju pravila (načela, norme) racionalnog organizovanja radnih procesa, kako u odnosu na radni učinak, tako i u odnosu na naprezanje ljudstva. Oni se mogu sistematizovati u nekoliko osnovnih grupa, kao što su: principi individualnog rada, u koje se ubrajaju: princip minimalnog psihofiziološkog naprezanja i princip minimalnog trajanja procesa rada i principi kolektivnog rada: jedinstva suprotnih interesa, jedinstva cilja i stimulisanja inicijative radnika.

Principi organizacije radnog mesta formulišu se po kriterijumima, kao što su uređenje radnih prostora (uz poštovanje sledećih pravila: minimalno kretanje radnika pri radu, da se omogući pravilno postavljanje predmeta rada pri obradi, da se obezbedi prilaz mašini sa svih strana, kao i prilaz sigurnosnim uređajima u slučaju opasnosti po radnika) i položaj radnika na radnom mestu (telo radnika mora biti u pravilnom položaju, sedište mora biti podešeno prema radniku i vrsti posla koji obavlja, itd.).

Principi organizacije individualnog rada su načela (pravila) na kojima počiva racionalno organizovanje rada pojedinca, bez obzira na to da li on radi izolovano $i$ sam ili u grupi (kolektivu). Smisao njihove primene je svođenje radnog napora na minimum uz istovremeno ostvarenje maksimalnog radnog efekta po jedinici radnog napora. 


\section{Raspored jedinica tehničke službe}

Jedinice tehničke službe se, načelno, $\mathrm{u}$ borbenim dejstvima razmeštaju u rejonima razvoja logističkih jedinica.

U oklopnim i mehanizovanim jedinicama, radi efikasnije podrške u održavanju, jedinice za tehničko održavanje razvijaju se izvan rejona razmeštaja logističkih jedinica, bliže prednjem kraju i, načelno, odmah iza borbenog rasporeda jedinica prve linije (u bataljonima), odnosno prvog borbenog ešelona (u brigadama). Jedinice za snabdevanje tehničkim materijalnim sredstvima razvijaju se u rejonima razmeštaja logističkih jedinica.

$\mathrm{U}$ artiljerijskim divizionima za podršku jedinice tehničke službe se razmeštaju 1 do $2 \mathrm{~km}$ iza rejona vatrenih položaja baterija.

U protivoklopnim artiljerijskim i raketnim divizionima jedinice tehničke službe se raspoređuju u protivoklopnom rejonu (POR), odnosno uporištu -1 do 2 $\mathrm{km}$ iza baterija.

$\mathrm{U}$ divizionima PVO jedinice tehničke službe se razmeštaju uz komandu diviziona i bateriju PVO koja je ostala uz komandu diviziona, ako se divizioni PVO upotrebljavaju po baterijama. Ukoliko se divizion upotrebljava kao celina, jedinice tehničke službe se, načelno, razmeštaju u rejonu razvoja logističkih jedinica.

U inžinjerijskim bataljonima (samostalnim četama) jedinice tehničke službe se razmeštaju uz komandu bataljona (samostalne čete) na težištu borbenih dejstava, načelno u visini drugog borbenog ešelona.

Brigadne jedinice za snabdevanje razvijaju se u okviru rejona razmeštaja logističke jedinice brigade.
Brigadne jedinice za održavanje razvijaju se u okviru rejona razmeštaja logističke jedinice brigade, osim u oklopnim i mehanizovanim brigadama čije se jedinice za održavanje razvijaju izvan rejona razmeštaja logističkog bataljona, bliže prednjem kraju.

U rejonima razmeštaja jedinice tehničke službe u ZTJ razvijaju sledeće elemente borbenog rasporeda - stanice za: tehničko snabdevanje (StTS), tehničko održavanje (StTOd), izvlačenje i evakuaciju (StIE), tehničku podršku (StTP), sabiralište oštećene tehnike (SOT), sabiralište ratnog plena (SRP), po potrebi i sabiralište uništene tehnike (SUT).

Površina rejona za razvoj stanica zavisi od jedinice koja se razvija, odnosno od brojnog stanja ljudstva, vrste i obima materijalnih rezervi i opreme koju ta jedinica ima, kao i od obima i prostornog razmeštaja infrastrukture u rejonu razmeštaja. U rejonima razmeštaja jedinice tehničke službe razvijaju stanice, unutar stanica sekcije, a unutar sekcija uređuju se odeljci sekcija i radna mesta.

Stanicu za tehničko snabdevanje (StTS) razvijaju odeljenja, vodovi ili čete za tehničko snabdevanje. Pri njihovom razvoju posebno se mora voditi računa o bezbednosnim rastojanjima između sekcija za smeštaj municije i pogonskih sredstava međusobno, o bezbednosnim rastojanjima između pojedinih vozila, stokova i grupa stokova s obzirom na količinu eksplozivnog materijala koja se $\mathrm{u}$ njima nalazi, kao i o rastojanjima između drugih objekata i elemenata u stanici i oko nje. U sastavu ovih stanica, ili u neposrednoj blizini, u napadnim dejstvima formiraju se sabirališta ratnog plena (SRP). U njima se vrši identifikacija i razvrstavanje sredstava. 
Stanicu za tehničko održavanje (StTOd) razvijaju odeljenja, vodovi i čete za tehničko održavanje. Površina rejona razmeštaja stanice zavisi od veličine jedinice koja razvija stanicu. Ove stanice, pored sekcija za održavanje pojedinih vrsta TMS i sekcije za snabdevanje rezervnim delovima, imaju i sekciju za opšte radove koja vrši usluge za sve ostale sekcije, izvođenjem bravarskih, zavarivačkih, kovačkih, limarskih, mašinskih, tapetarskih, farbarskih, autolakirerskih, elektromehaničarskih, stolarskih, radova precizne mehanike i sličnih radova.

U sastavu ovih stanica ili u neposrednoj blizini formiraju se sabirališta oštećene tehnike (SOT). U njima se identifikuje neispravnost i razvrstavaju sredstva po vrstama i obimu oštećenja radi opravke u StTOd ili radi upućivanja na remont.

Stanicu za izvlačenje i evakuaciju razvijaju jedinice za održavanje koje u svom sastavu imaju, ili su im pridodata, sredstva za izvlačenje i evakuaciju, kao što su: automobili za izvlačenje, tenkovi za izvlačenje, autodizalice, dizalice za borbena vozila, vučni vozovi za borbena i neborbena vozila. Razvijaju se na težištu borbenih dejstava, najčešće između prvog i drugog borbenog ešelona ili $u$ blizini SOT-a i posebno su značajne za oklopne i mehanizovane jedinice. Stanice za izvlačenje i evakuaciju mogu se razvijati i u okviru StTOd.

Stanicu tehničke podrške razvijaju tehnička odeljenja u rejonima razmeštaja logističkih jedinica bataljona-diviziona. U njima se rešavaju objedinjeno zadaci i održavanja i snabdevanja TMS, angažovanjem formacijskih i pridodatih resursa, mada su trenutno kapaciteti za održavanje nešto drugačije organizovani.
Jedinice tehničke službe izvršavaju zadatke iz jednog ili više rejona razmeštaja. U tim slučajevima stanice koje formiraju jedinice tehničke službe dele se na osnovne (npr. StTS-1), koje izvršavaju zadatke tehničke podrške za glavne snage, izdvojene (npr. StTS-2) za tehničku podršku jedinica na izdvojenom - pomoćnom pravcu borbenih dejstava, te isturene (npr. StTSIs) za rešavanje zadataka tehničke podrške jedinica sa posebnim zadacima (zadaci u pretpolju, pri nasilnom prelasku reke i dr.).

\section{Prostorna integracija i izbor rejona razmeštaja jedinica TSI}

Pri izboru lokacije za razvoj jedinica tehničke službe odluke se moraju donositi kompromisno, uz uvažavanje određenih taktičkih, organizacionih i tehnoloških kriterijuma, i nastojanje da se najviše koriste postojeći objekti i infrastruktura teritorije, uz minimalna ulaganja resursa svih vrsta za podešavanja postojećih objekata i uređenje zemljišne prostorije.

Izborom adekvatnog načina upotrebe jedinica tehničke službe i organizovanja rada u njima potrebno je izvršiti odgovarajuću integraciju njihovih elemenata: opreme, radnih mesta, elemenata za opsluživanje rada i obezbeđenje uslova rada, radne snage i dr. Treba uspostaviti dobru prostornu međuzavisnost pojedinih komponenata, odnosno tehnologiju i ljude uklopiti u jedan sistem, a zatim valjanim dnevnim vođenjem stvarati uslove za realizaciju namenskih zadataka.

Dobra prostorna integracija elemenata jedinica tehničke službe treba da obezbedi: 
- efikasno iskorišćenje ljudskih, materijalnih, energetskih i informacionih resursa, bezbednost i zaštitu;

- visok stepen iskorišćenja prostora (površina, zapremina, nosivost);

- povoljno i efikasno kretanje ljudstva, predmeta rada, opreme i materijala kroz pojedine faze procesa;

- pogodnu radnu sredinu i neophodne sanitarno-tehničke uslove;

- lak pristup opremi radi održavanja i popravki.

Loša integracija elemenata jedinica tehničke službe dovodi do:

- stvaranja uskih grla i produženja radnog ciklusa;

- pojave zastoja, zatrpanosti radnih mesta i prolaza;

- pada kvaliteta opsluživanja i stvaranja loših bezbednosnih uslova;

- povećanja visine troškova poslovanja, itd.

Osnovni kriterijumi pri formiranju prostornih struktura jedinica su:

- tehnički - intenzitet toka materijala, dužina transportnih puteva, vreme i transportni učinak, autonomnost u obezbeđenju energijom i ostalim potrebama za nesmetan rad, itd.;

- ekonomski - investicioni, eksploatacioni i drugi troškovi;

- vojnooperativni - vreme zadržavanja na izabranoj lokaciji, zahtevani nivo gotovosti za borbena dejstva i dr.

Razmeštaj opreme jedinica tehničke službe može se izvršiti na dva načina: prema vrsti procesa (grupisanje opreme prema funkciji koju obavljaju) i prema redosledu tehnoloških operacija (oprema se postavlja u liniji, a redosled je diktiran redosledom poslova). Obično se ova dva navedena načina kombinuju.
$\mathrm{Na}$ izbor načina organizovanja rada u jedinicama tehničke službe utiču i predmet rada (TMS, materijal), kvantitet (količina i obim) rada, tehnološki proces - postupak, operacije i redosled, opsluživanje rada i obezbeđenje uslova rada, vreme - povezuje prethodna četiri elementa (uravnoteženje operacija, opreme, sinhronizovan rad svih učesnika).

Rad u jedinicama tehničke službe može da se organizuje:

- prema vrsti procesa koji se odvija $\mathrm{u}$ pojedinim funkcionalnim celinama (oprema i uređaji prema vrsti posla);

- prema redosledu izvođenja tehnoloških operacija (grupisanje opreme i uređaja prema redosledu poslova);

- kombinovanjem prvog i drugog načina (proizvodnja u ćelijama);

- sa fiksnim pozicijama proizvoda proizvod je stacionaran, a ostali resursi se prinose (ljudi, oprema, alati, materijal i dr.), što se može javiti u jedinicama za održavanje pri održavanju težih TMS (tenkovi, oklopni transporteri, samohodna oruđa).

Brigadne jedinice za održavanje angažuju se kao celina u rejonima u kojima razvijaju stanice. Moguće je da se određene mešovite ekipe $\mathrm{i}$ tehnološke celine upućuju u potčinjene jedinice radi ojačanja po tehničkoj podršci, a moguće je i da od svojih resursa formiraju više elemenata borbenog rasporeda: osnovne stanice, isturene i izdvojene stanice, sabirališta oštećene tehnike, stanice za izvlačenje i evakuaciju i dr. Pri izvršavanju konkretnih zadataka jedinice za održavanje angažuju pojedince, tehnološke celine, mešovite ekipe ili kompletne organizacione (formacijske) celine. 
Brigadne jedinice za snabdevanje upotrebljavaju se kao celina $u$ rejonima $u$ kojima razvijaju stanice, u određenim situacijama određene mešovite sastave upućuju u potčinjene jedinice radi ojačanja i osamostaljivanja po tehničkoj podršci, a moguće je i da od svojih resursa formiraju više elemenata borbenog rasporeda: osnovne stanice, isturene i izdvojene stanice, sabiralište ratnog plena i dr.

Izbor rejona za razvoj jedinica TSl u ZTJ je višekriterijumski problem, a odluke o izboru moraju se donositi uz pažljivo prethodno odmeravanje vrednosti definisanih kriterijuma.

Pri izboru rejona razmeštaja jedinica TSl moraju se uvek razmatrati konkretni uslovi u kojima se jedinica nalazi. U obzir se moraju uzeti namena i zadaci jedinice tehničke službe, njena organizacijsko-formacijska struktura, lični i materijalni sastav i borbeni kvalitet, vid borbenih dejstava, borbeni raspored i dinamika angažovanja jedinice koju podržava, prostorne mogućnosti rejona, uticaj neprijatelja, zemljišta i vremena.

Mesto i vreme formiranja stanica, njihov sastav, vreme i pravce premeštanja jedinicama tehničke službe određuje pretpostavljeni komandant, odnosno, pomoćnik komandanta za logistiku, na osnovu predloga organa tehničke službe, po mogućnosti, nakon izvršenog izviđanja.

Kada izviđanje nije moguće mesto razmeštaja određuje se po karti, a komandir jedinice tehničke službe, bilo putem izvidnice, bilo neposredno po dolasku u rejon razmeštaja, stiče uvid u stanje (izviđanjem) i razmeštaj jedinice tako da se na najpogodniji način iskoriste prednosti zemljišta i postojeće infrastrukture.
Kad god je to moguće, treba izabrati rejon razmeštaja koji sa raspoloživom infrastrukturom zadovoljava sledeće osnovne uslove:

- da omogućuje rastresit raspored, utvrđivanje i maskiranje;

- da omogućuje život, rad, borbenu obuku i odbranu stanice;

- da omogućuje smeštaj, odmor, kupanje, presvlačenje i zagrevanje ljudstva;

- da se nalazi u blizini komunikacija kojima može da se stigne do resursa pretpostavljene komande i da je povezan sa putevima koji izvode ka borbenom rasporedu jedinica;

- da pruža povoljne uslove za sprovođenje mera borbenog obezbeđenja;

- da omogućuje nesmetan manevar vozilima i ostalom opremom unutar stanice;

- da ima uslove za snabdevanje vodom, električnom energijom i drugim potrebama za život i rad jedinice tehničke službe;

- da se u blizini ne nalaze unosni ciljevi za dejstvo neprijatelja i ciljevi čijim bi oštećenjem došlo do ugrožavanja životne sredine;

- da se ne nalazi u blizini sakralnih objekata i zaštićenih rejona.

Često će biti teško naći prostor koji zadovoljava sve navedene uslove, kao i lokaciju koja predstavlja, između mogućih - raspoloživih, optimalno rešenje. Zato je nužno da komandir uskladi zahteve za razmeštaj i mogućnosti koje pruža određeni prostor, a ukoliko uslovi dopuštaju dodatnim radovima i merama treba obezbediti što povoljnije uslove za rad i bezbednost ljudstva.

Objekti u koje se smešta ljudstvo jedinica TSl treba da pružaju odgovarajuće 
uslove za bezbedan rad u smenama, odmor, održavanje lične higijene, komuniciranje i bezbedno čuvanje poverljivih dokumenata.

\section{Razvijanje i uredenje stanice}

Pri razvoju stanica, sekcija, radnih mesta i razmeštaja pojedinačnih materijalnih sredstava treba zadovoljiti načelne norme do kojih se došlo na osnovu iskustva, odnosno određenih teorijskih i empirijskih saznanja.

Razvijanje stanice načelno se vrši sa zastankom na liniji razvođenja, a kada to nije moguće, onda neposredno iz marševske kolone jedinice. Linija razvođenja je 300 do $800 \mathrm{~m}$ ispred rejona na kojem se razvija stanica, na mestu pogodnom za sklanjanje i maskiranje vozila, a na njoj se jedinica zadržava najviše jedan čas.

Kada to situacija nalaže, komandir može da izda elemente zapovesti za razvoj stanice, u dva dela. U prvom delu reguliše osnovni raspored i razvijanje sekcija, a neposredno posle razvijanja jedinice komandir po ostalim elementima reguliše dalji postupak i rad jedinice.

U zavisnosti od veličine i vrste jedinica tehničke službe, specifičan je i rad u svakoj od njih. Ipak, mogu se uopštiti neke osnovne aktivnosti koje su zajedničke za jedinice za snabdevanje i jedinice za održavanje TMS. Postupak razvoja stanice odvija se po sledećoj dinamici:

- postaviti neposredno borbeno obezbeđenje, dežurne organe i izdati zadatke obezbeđenju i dežurnim organima;

- razmestiti vozila po sekcijama;

- orijentisati ljudstvo u prostoru, vremenu i situaciji;
- organizovati sistem vatre;

- razmestiti opremu i materijal;

- razviti organizaciono-tehnološke celine i radna mesta;

- razviti mesto komandira (osmatračnicu komandira osnovne jedinice);

- smestiti i obezbediti ljudstvo od nepovoljnog dejstva vremenskih uslova (podići šatore ili smestiti ljudstvo u čvrste objekte);

- organizovati kretanje u rejonu stanice, $\mathrm{i}$

- oformiti potrebna borbena dokumenta.

Starešine potčinjenih jedinica vode svoje jedinice na mesta razmeštaja, određuju ljudstvo za izvršenje pojedinih zadataka (izbor mesta za postavljanje pojedinačnih TMS za rad, izbor mesta za odmor ljudstva, izbor mesta za zaklone za vatreno dejstvo i zaštitu, izbor lokacija za izradu skloništa za ljudstvo i TMS, podizanje šatora, maskiranje, itd.) i neposredno rukovode razmeštajem svojih jedinica.

U okviru sekcija stanice za snabdevanje obavezno se preciziraju mesta za sledeće (slika 1) organizaciono-tehnološke celine: mesto komandira sekcije; mesto za sačekivanje transporta iz pretpostavljene komande; mesto za prijem sredstava iz pretpostavljene komande; mesto za vozila natovarena materijalnim sredstvima, mesto za prazna vozila; mesto za stokiranje TMS, mesto za manipulaciju (pretakanje, prepakivanje, slaganje i sl.); mesto za izdavanje TMS; mesto za praznu ambalažu, i mesto za grupisanje transportnih sredstava za dotur do potčinjenih jedinica.

Ubojna sredstva se stokiraju po grupama i vrstama unutar grupe, vodeći računa o laboračnim serijama $\mathrm{i}$ težinskim oznakama. 


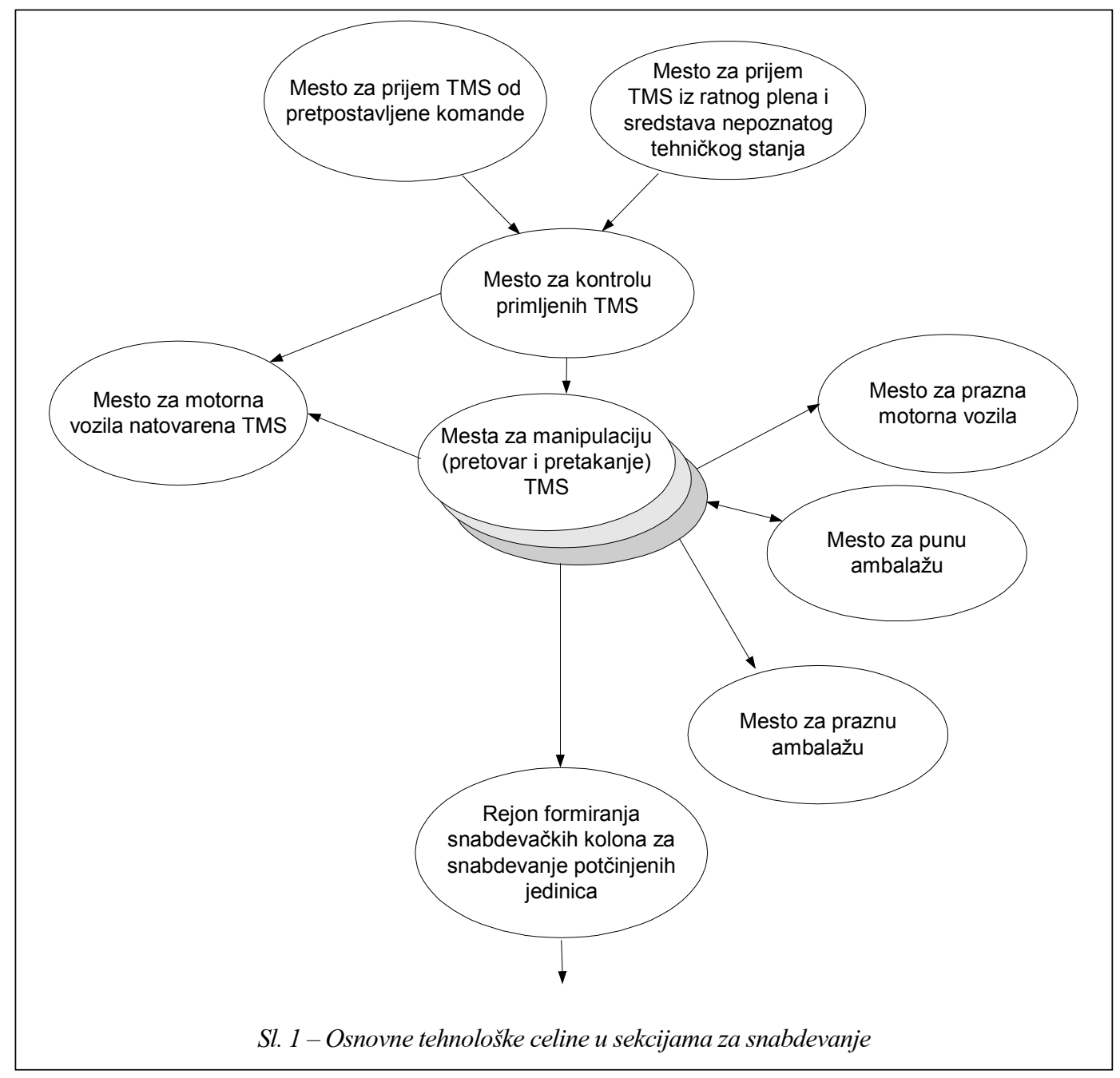

Pri stokiranju municije teži se da različit asortiman municije bude na jednom mestu.

Pogonska sredstva stokiraju se odvojeno po vrstama, a u okviru vrste prema ambalaži. Ulja i masti za podmazivanje, tečnosti za hidraulične sisteme $\mathrm{i}$ ostala pogonska sredstva stokiraju se po vrstama i pakovanjima, odvojeno od pogonskih sredstava. Sredstva za sisteme za hlađenje stokiraju se odvojeno od goriva.

Pri razvoju pojedinih elemenata sekcija i organizacije rada u njima posebno treba voditi računa o bezbednosnim rastojanjima između sekcija za smeštaj municije i goriva i o rastojanjima unutar pojedinih sekcija, te o rastojanjima između pojedinih stokova i vozila u zavisnosti od količine eksplozivnog materijala (čistog eksploziva) odloženog na jednom mestu.

Takođe, adekvatnim početnim razvojem treba stvoriti uslove za što manje pomeranje pojedinih elemenata sekcija u kasnijem periodu, radi ostvarenja rastresitijeg rasporeda, utvrđivanja i maskiranja. 
Raspored i rad pojedinih sekcija u celini treba da bude takav da organizacioni i tehnološki gubici vremena i materijala budu minimalni, naprezanje resursa što manje, raspoloživi resursi iskorišćeni maksimalno i da se može organizovati kružna odbrana rejona razmeštaja, a u slučaju dejstava neprijatelja sa distance $\mathrm{i}$ iz vazdušnog prostora gubici u ljudstvu i materijalnim sredstvima budu minimalni. Tom cilju treba prilagoditi organizaciju rada i postupke celokupnog ljudstva $\mathrm{u}$ stanici.

U okviru sekcija stanice za tehničko održavanje (slika 2) obavezno se preciziraju mesta za sledeće tehnološke celine: za rad komandira sekcije; za prijem i raz- vrstavanje sredstava (po grupama i vrstama sredstava, a u okviru grupe i vrste sredstava po vrsti i obimu neispravnosti sredstava); za grubo čišćenje i pranje; za defektažu neispravnih sredstava; za otklanjanje neispravnosti i oštećenja; za priručni magacin; za opravljena sredstva; za sredstva koja čekaju na održavanje zbog nedostatka r/d; za delove i materijal koji se šalju na regeneraciju; za grupisanje sredstava za evakuaciju prema višim nivoima za održavanje; za sredstva ratnog plena.

Uređenje stanice obuhvata radove kojima se stvaraju dodatni uslovi za njihovo kvalitetno funkcionisanje, izvršavanje namenskih zadataka, obezbeđenje, iz-

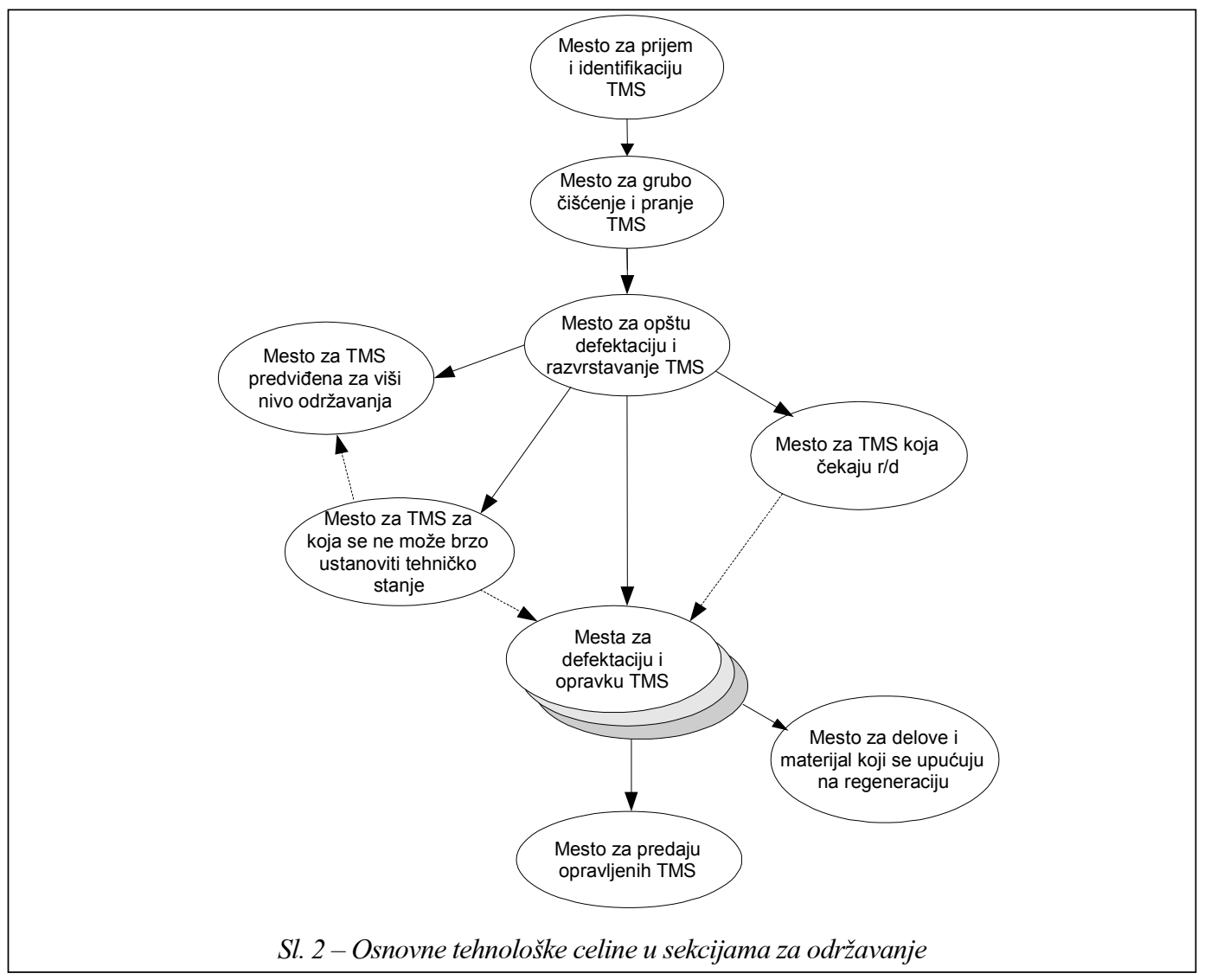


vođenje borbenih dejstava i preživljavanje, ukoliko ljudstvo, materijalna sredstva i rejon budu ugroženi.

Ukoliko rejon razmeštaja nije ranije uređen, radovi na uređenju mogli bi se obavljati sledećim redom: maskirati vozila i ostala materijalna sredstva a zatim urediti: mesta za smeštaj ljudstva (zatezanje šatora, uređenje čvrstih objekata, izrada sanitarnih elemenata, itd.), mesta za smeštaj pojedinih TMS; zaklone za vatreno dejstvo i zaštitu, mesta za rad; osmatračnicu komandira osnovne jedinice; skloništa za ljudstvo i materijalna sredstva; mesta za prijem i izdavanje TMS; puteve u rejonu stanica i mesta za obedovanje i odmor ljudstva.

Kada se u rejonu razmeštaja nalaze objekti kao što su: pećine, rovovi, tuneli, otvoreni kopovi, radionice, servisne i pumpne stanice, treba ih u svim prilikama urediti i koristiti kao mesta za rad ili skloništa za ljudstvo i materijalna sredstva. Time se radovi na uređenju stanice svode na najmanju meru, a resursi racionalno koriste.

Nakon izvršenog uređenja rejona stanice treba nastaviti sa obukom i konkretno proraditi postupak stanice u slučaju napada sa zemlje i iz vazdušnog prostora i obezbeđenje logističkih ekipa $u$ kretanju na konkretnim putevima dotura $\mathrm{i}$ evakuacije.

Komandir osnovne jedinice u okviru dodeljenog rejona za razvoj stanice organizuje zajedničke elemente borbenog obezbeđenja (dežurna jedinica, interventna jedinica, straže, patrole, zasede, objavnice), određuje rejone odgovornosti nižih jedinica - sekcija, organizuje aktivnosti značajne za život i rad osnovne jedinice kao celine, sinhronizuje i povezuje u skladnu svrsishodnu celinu aktivnosti vojnog kolektiva i uspostavlja sistem komandovanja u rejonu razmeštaja.

Komandir osnovne jedinice nakon toga izrađuje šemu razmeštaja sa elementima borbenog osiguranja i osnovama sistema vatre (plan vatre).

Komandiri vodova (odeljenja) određuju svakom čoveku mesto u slučaju neposrednog napada na stanicu, osnovni i dopunski pravac dejstva, susede i saopštavaju im mesto komandira u borbenom rasporedu jedinice.

Komandir osnovne jedinice i potčinjeni komandiri organizuju sistem vatre u skladu sa dobijenim zadatkom i raspoloživim resursima, a na osnovu procene situacije, tako da se može brzo ostvariti koncentracija vatre i manevar vatrom, $\mathrm{u}$ skladu sa razvojem borbene situacije. Od posebne je važnosti da sistem vatre bude usklađen sa sistemom prepreka. U odbrani stanice sistem vatre obuhvata dejstvo svih organskih i pridodatih vatrenih sredstava, sredstava za podršku iz dubine i vatru iz susednih rejona kad god je to moguće i opravdano.

$\mathrm{Za}$ organizovanje sistema vatre komandiri čete i voda postavljaju konkretne vatrene zadatke potčinjenim jedinicama $\mathrm{i}$ elementima borbenog rasporeda, određujući im zone i pravce dejstva, prednju granicu pojasa glavne zaprečne vatre i mesta (linije) za pripremu raznih vrsta vatri. Zone i pravci dejstva susednih jedinica i vatrenih sredstava redovno treba da se delom preklapaju.

Za osiguranje krila i bokova i organizovanje kružne odbrane od otpornih tačaka (kada se organizuju) određuju se rezervni vatreni položaji za pojedina odeljenja i vatrena sredstva. 
Za odbijanje iznenadnih napada neprijatelja i održavanje visokog nivoa borbene gotovosti određuju se dežurna vatrena sredstva (puškomitraljezi, mitraljezi, bestrzajna oruđa). Ona otvaraju vatru sa rezervnih i privremenih vatrenih položaja, neutrališući i uništavajući neprijateljeve izviđače i manje grupe, koje pokušavaju da se probiju radi izviđanja ili upada u rejon odbrane stanice.

Dobrom organizacijom treba obezbediti da jedinica uvek bude u mogućnosti da otvori brzu i preciznu vatru ukoliko je napadnuta. Radi postizanja što boljih rezultata vatrenog dejstva treba pravilno izabrati ciljeve (težišta i prioriteti), obezbediti koncentraciju dovoljno jake i precizne vatre (primenjujući manevar vatrom i oruđima) i izabrati pravo vreme za otvaranje vatre. Takođe, treba obezbediti da jedinica, ukoliko je izrazito ugrožena, može organizovano izvršiti premeštanje u naredni rejon.

\section{Organizacija rada u stanicama za snabdevanje i održavanje}

Dobra organizacija rada u stanicama bitan je uslov da stanice efikasno i efektivno funkcionišu, i da kvalitetno izvršavaju namenske zadatke.

Organizacija rada u stanicama podrazumeva:

- definisanje organizacione strukture za rad - izvršenje zadataka, život i borbu;

- prostorni razmeštaj elemenata organizacione strukture;

- definisanje tokova kretanja ljudstva, materijalnih sredstava, dokumenata i informacija;

- definisanje zvaničnog komuniciranja, organizovanje i uspostavljanje veze;
- organizacione odnose između rukovodilaca i izvršilaca, između rukovodilaca međusobno i izvršilaca međusobno;

- definisanje načina donošenja odluka i rukovođenja;

- preciziranje zadataka koje izvršavaju pojedini elementi organizacione strukture;

- postupnost - metodiku izvršavanja zadataka;

- posedovanje dokumenata, vojnostručne literature i normativa koji se koriste u radu;

- obezbeđenje kvalitetnog funkcionisanja vojnog kolektiva;

- definisanje nadležnosti u komandovanju pri upotrebi privremenih sastava;

- preciziranje obima uređenja radnih mesta;

- definisanje resursa za zadatke visokog prioriteta;

- preciziranje stepena uređenosti rejona razmeštaja i obezbeđenja stanica i njihovih elemenata, u mestu i pokretu;

- definisanje pokazatelja uspešnosti funkcionisanja;

- koordinaciju aktivnosti formacijskih jedinica i privremenih sastava;

- analizu rada i uspešnosti poslovanja.

Mikroorganizacija rada u stanicama za snabdevanje i održavanje podrazumeva preciziranje određenih zajedničkih elemenata. To su mesta: za neposredno borbeno osiguranje, pravce kretanja i rejone osmatranja; za dežurne organe; komandira i njihove zamenike; za skloništa ljudi i skloništa za materijalna sredstva; za odmor i zagrevanje ljudstva; za umivanje, kupanje i presvlačenje ljudstva; za popunu tehničkih materijalnih sredstava pogonskim gorivom; za kondicioniranje hemijskih izvora struje; za odlaganje ma- 
terija štetnih (opasnih) po okolinu; za obezbeđenje - snabdevanje vodom u rejonu razmeštaja; za obedovanje; za pranje posuđa; za odlaganje sudova sa vodom; za odlaganje otpadnih materijala; za razvoj i uređenje pojedinačnih radnih mesta, svih vojnoevidencionih specijalnosti; za svakog pojedinca u borbenom rasporedu za odbranu stanice; za poljski nužnik.

Pokazatelji uspešnosti funkcionisanja jedinica TSl mogu se podeliti na neekonomske i ekonomske. Neekonomski pokazatelji su: borbena gotovost, efektivnost sistema, kvalitet proizvoda, radova i usluga koje realizuju jedinice TSl. Ekonomske pokazatelje uspešnosti funkcionisanja jedinica TSl čine: organizovanost sistema, produktivnost (proizvodnost), ekonomičnost i rentabilnost, odnosi troškova i obima poslovanja i ukupan radni učinak sistema.

\section{Zaključak}

Za pravilan razvoj i organizaciju rada jedinica tehničke službe odgovorne su komande u čijem su one sastavu, a razmeštaj se ostvaruje na osnovu usvojenih načela, iskustvenih normi i teorijskih saznanja vezanih za složene vojne organizacione sisteme. Pravilnim razvojem i kvalitetnom organizacijom rada $u$ jedinicama TSl, kvalitetnim komandovanjem i upornim radom svih pripadnika, a pre svega starešina, stvaraju se uslovi za uspešno izvršavanje zadataka, bezbedan život i rad, kao i opstajanje na bojištu.

Organizacija rada u jedinicama tehničke službe u združenim taktičkim jedinicama, u borbenim dejstvima, zahteva posmatranje jedinica TSl u svojoj složenosti i sa različitih aspekata. Pored toga zahteva pravilan izbor rejona razmeštaja, smeštaj ljudstva i materijalnih sredstava, stvaranje uslova za život, rad, zaštitu i izvršavanje namenskih zadataka. To dalje podrazumeva stavljanje ljudstva i materijalnih sredstava u funkciju, preciziranje mesta i uloge svakog elementa i podsistema u okviru celine i celine (jedinice) $u$ okviru više celine (jedinice).

Organizacija rada $u$ jedinicama tehničke službe podrazumeva i regulisanje načina realizacije namenskih zadataka, tokova kretanja ljudstva, dokumenata, informacija i materijala.

$\mathrm{S}$ obzirom na to da u našim vojnim časopisima ima malo radova o funkcionisanju i upotrebi logističkih jedinica na taktičkom nivou organizovanja Vojske ovaj rad može dati doprinos unapređenju trupne prakse i poslužiti kao polazna osnova za dalja teorijska razmatranja funkcionisanja i upotrebe jedinica TS1 u borbenim dejstvima. U izvesnoj meri rad može poslužiti i kao poticaj izradi nove normative koja reguliše upotrebu logističkih jedinica.

Potrebe prakse, zahtevi vremena i savremeni upravljački trendovi zahtevaju da se funkcionisanje i upotreba jedinica tehničke službe, kao složenih organizacionih sistema, odvijaju planski i na organizovan način. Ovim zahtevom daje se doprinos normativnom uređivanju ove oblasti, adekvatnom primenom propisanog i kvalitetnim upravljanjem.

Postojeća normativa koja reguliše upotrebu jedinica TSl predstavlja solidnu polaznu osnovu za izradu nastavne literature vezane za funkcionisanje i upotrebu 
jedinica. Zasnovana je, uglavnom, na empirijskim saznanjima koja već dugo nisu aktuelizovana, dalje razrađivana $\mathrm{i}$ unapređivana, iako praksa to zahteva.

$\mathrm{U}$ sferi organizacionih promena $u$ Vojsci, neprekidno treba sagledavati organizaciona ograničenja sistemske prirode, dostignuti stepen razvoja tehničkih materijalnih sredstava, izmene obeležja savremenog rata i promene i modernizaciju organizacionih i tehnoloških rešenja u domenu logističke podrške na strategijskom i operativnom nivou i uticaj na funkcionisanje logističke podrške $u$ jedinicama na taktičkom nivou.

Takođe, pri iznalaženju budućih rešenja za funkcionisanje i upotrebu jedinica tehničke službe (logističkih jedinica), neophodno je ostvariti bolju vezu teorije i savremene prakse i iznaći optimalna re- šenja koja će ući u novi doktrinarni sistem logističke podrške.

Literatura:

[1] Iskustva jedinica službi VJ nivoa bataljona u borbenim dejstvima tokom suprotstavljanja agresiji NATO-a na SRJ (projekat), IRV SŠONID GŠ VJ, Beograd, 1999.

[2] Primena logističkog principa u organizaciji Vojske (projekat), SLGŠ VJ, Beograd, 2000.

[3] Maksić, R.; Andrejić, M.; Nikolić, N.: Taktika tehničke službe (udžbenik u štampi), UŠiO GŠ VSCG, Beograd, 2004.

[4] Erić, D.: Uvod u menadžment, Ekonomski fakultet, Beograd, 2000.

[5] Jovanović, B.: Uvod u teoriju vojnog rukovođenja, VIZ, Beograd, 1984

[6] Uputstvo za primenu kriterijuma ešeloniranja RMR u VJ, OpU GŠ VJ, Beograd, 2003.

[7] Kriterijum OFS LiM sastava jedinica za TOd i TSn u ratu i miru, TU SP GŠ VJ, Beograd, 1997.

[8] Uputstvo za rad četnih - baterijskih mehaničara, TU SP GS̆ VJ, Beograd, 1998.

[9] Pravilo tehničke službe, SSNO, Beograd, 1979.

[10] Pozadinske jedinice taktičkih jedinica KoV, pravilo, OUP, SSNO, Beograd, 1986.

[11] Odeljenje, vod i četa tehničkog snabdevanja - održavanja, upotreba i rad, TU SSNO, Beograd, 1978.

[12] Kidd, Martine, S.: Training Logisticians in the Objective Force, Army Logistician, sep. 2003. 


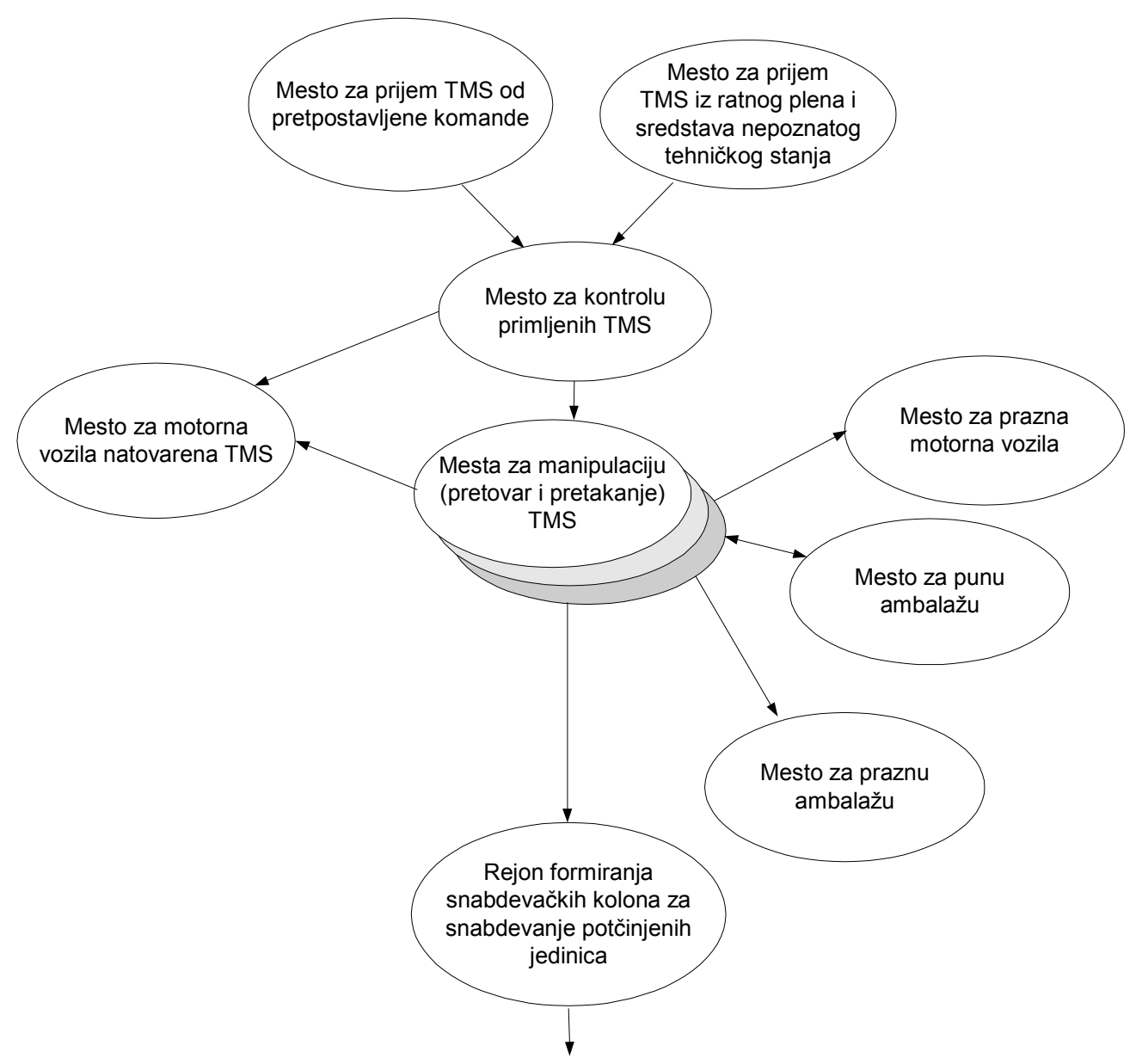

Sl. 1 - Osnovne tehnološke celine u sekcijama za snabdevanje 


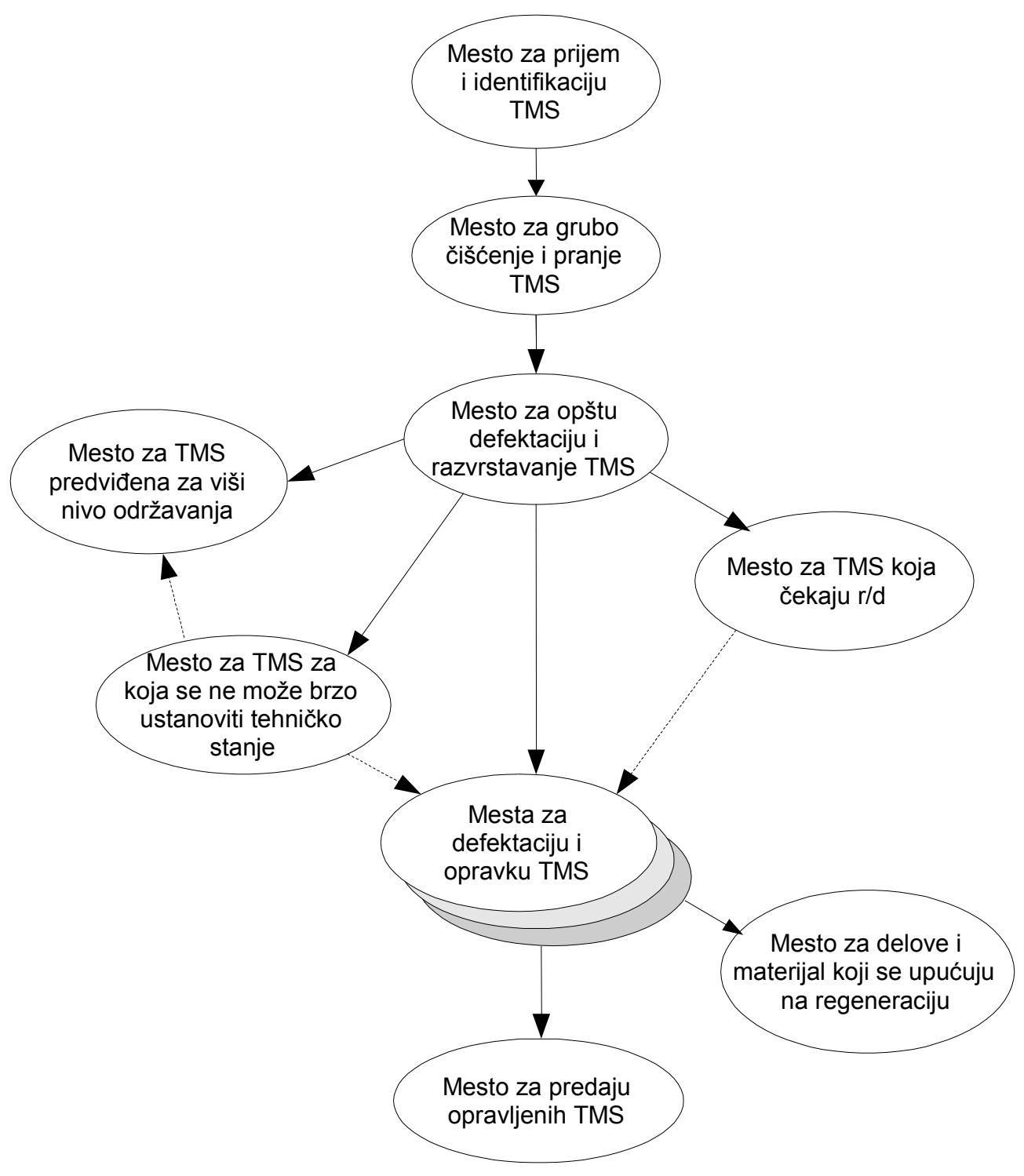

Sl. 2 - Osnovne tehnološke celine u sekcijama za održavanje 